\title{
Performance Evaluation of Self Propelled Reaper Binder for Harvesting of Wheat Crop
}

\author{
Anurag Patel $^{1 *}$, Rajkishor Singh ${ }^{1}$, Prabhakar Shukla ${ }^{2}$ and S.C. Moses ${ }^{1}$ \\ ${ }^{1}$ VIAET, Sam Higginbottom University of Agriculture Technology and Sciences, Allahabad \\ (U.P.), India \\ ${ }^{2}$ ICAR-Central Institute of Agricultural Engineering, Bhopal (M.P.), India
}

*Corresponding author

\section{A B S T R A C T}

\section{Keywords}

Wheat crop harvesting, Self propelled reaperbinder, Fuel consumption, Cost economics

\section{Article Info}

Accepted: 10 November 2018 Available Online: 10 December 2018

\begin{abstract}
In India harvesting of cereal crops is one of the major attentive agricultural operations in agriculture production, which demands considerable amount of labours. The availability and cost of labour during wheat crop harvesting season are serious problems. It is therefore, essential to adopt the mechanical methods so that the timeliness in harvesting operation could be ensured and field losses are minimized to increase production on the farm. The objective of this study was to evaluate the field performance of self propelled reaper-binder at farmer's field. The effective field capacity of the reaper binder was found as $0.17 \mathrm{ha} \mathrm{h}^{-1}$ with a field efficiency of 78.49 per cent at an average operating speed of $2.55 \mathrm{~km} \mathrm{~h}^{-1}$. The fuel consumption was observed as $1.12 \mathrm{l} \mathrm{ha}^{-1}$. The harvesting cost and losses were Rs. $3235.11 \mathrm{ha}^{-1}$ and $25.42 \mathrm{~kg} \mathrm{ha}^{-1}$ respectively. The feedback of machine operation was collected by some farmer's at the time of harvesting and the performance of the reaper binder at the farm was satisfactory.
\end{abstract}

\section{Introduction}

Harvesting of crop is one of the most labour intensive operations in agriculture. Yet the most prevalent method of harvesting of crops in India is the manual methods which is time and labour consuming, involves 18 to 25 mandays $\mathrm{ha}^{-1}$. It is estimated that harvesting and threshing consumes about one third of the total labour requirement of complete crop production system. In the multiple cropping systems with short duration high yielding varieties, less time is available between harvesting of one crop and sowing of the subsequent. Rapid urbanization and migration of agricultural labour resulted in late harvesting, causing heavy grain losses (Iqbal 1985). Harvesting of wheat crop in eastern U.P. is mainly done manually by hand using sickle which is labour intensive and delayed due to labour shortage to overcome. (Saxena and Ojha, 1985) reported that losses are minimum at optimum harvesting time, also late harvesting causes 3 percent loss in the first week to about 7 percent loss of grain in the third week after optimum time of 
harvesting. In spite of the fact that large number of tractors, diesel engines and improved agricultural machineries, the farmers prefer traditional tools and implements which usually are by either human or animal operated. Albeit these traditional tools have low initial cost but very slow resulting in heavy operational cost. Hence, this study was taken to evaluate the performance of self propelled reaper binder for harvesting of wheat crop.

Design of reaper binder, one trailed type P.T.O. operated and the other a four wheeled, riding type, self-propelled machine, were conducted. The self-propelled unit provided much better maneuverability and other better visibility and control by the operator in comparison to trailed machine (Mishra, 1983).

Conducted a field test on three locally manufactured and commercially available tractor front-mounted reaper binders on wheat crop in Pakistan. The average field capacity was about 0.4 ha $\mathrm{h}^{-1}$ with $4 \%$ grain loss. Labour input in mechanical reaping was about 5 man-h ha ${ }^{-1}$ compared to 184 man $-\mathrm{h} \mathrm{ha}{ }^{-1}$ in manual operation. The mechanical harvesting was lower than that of manual harvesting. Farmer's indicated performance for mechanical harvesting due mainly to shortage of harvest labour (Gajendra Singh, 1988).

Developed two models of reaper binder widowers for harvesting crops. The first model had a cutter bar of $1.6 \mathrm{~m}$ width, which equaled seven rows of crop at $22.8 \mathrm{~m}$ row to row spacing. This model was selected for use with a power tiller and the other having 2.05 $m$ cutting width was used with a tractor. The performance studies showed that the cost of operation and labour requirements for reaper binder windrowers were lower than manual harvesting. The average field capacities value was 0.38 hectare per hour and was higher in comparison to the field capacities as achieved by others so far. The cost of operations was lowered by 20 to 38 percent. The total harvesting losses were 4 to 6 percent of grain yield when grain moisture content was 7 to 11 percent. The labor requirements were reduced to 40-42 man-hours per hectare (Devenani and Pandey, 79-1985).

Designed and developed a simple and rugged oxen drawn reaper for harvesting pulses and oil seed. It was light weight machine that required less draft as compared to others. The crops harvested was delivered in uniform bunches behind the cutter bar. The special feature of the machine was transformation of low soil thrust developed from traction wheel into higher force for cutting crops through crank and lever mechanism at the cutter bar (Yadav, 1992).

Studied the constraints in adoption of fodder harvester by interviewing 51 respondents spreading over 37 villages in Hisar and Sirsa districts of Haryana (India). The interviews were categorized as machine owners, customhirers and other and their response were recorded in yes or no. The various constraints were divided into three category viz. economical, operational and infrastructural constraints. The major operational constraints were requirements of accessories (100 percent), requirements, of manual harvesting on corners of fields (100 percent), inability to harvest lodged crop ( 97.35 percent), problems in harvesting at high crop moisture content (96.04 percent), too many adjustments requirement before operation 987.2 percent). The infrastructural constraints were inadequate repair facilities (100 percent) and non-availability of machine locally $(90.21$ percent). The economic constraints were high cost of fodder harvester (75.83 percent), directly to collect the crop as compared to manual harvesting (24.16 percent) (Tuteja, 1996). 
Study was conducted to compare technical feature and field performance of two commercially available models of combine harvesters namely: tractor side mounted combine a tractor riding type combine. Both the machines were evaluated or harvesting wheat and paddy crop. Rack and shoe losses and grain breakage in tank for wheat crop was 0.18 and 3.62 percent. Visibility and ease of operation was better in case of side mounted combine. During operation no breakdown in both the combine was observed besides minor adjustments (Manes, 2003).

Study was undertaken to determine the field losses and cost of economics of combine harvester and combination of self-propelled vertical conveyor reaper with thresher. The analysis of data and results obtained from the comparative evaluation of both the machines shows that the total field loss of combine harvester i.e. $4.20 \%$ was less than the combination of self-propelled vertical conveyor reaper with thresher i.e. $10.57 \%$. The cost of operation for combine harvester was 817.84 Rs. ha ${ }^{-1}$ which was less than the combination of self-propelled vertical conveyor reaper with thresher i.e. 1816.79 Rs. $\mathrm{ha}^{-1}$ Thus, the combine harvester and combination of self-propelled vertical conveyor reaper with thresher were more suitable for large fields and small fields respectively (Pathak, 2008).

\section{Materials and Methods}

The performance evolution of reaper binder was conducted in research farm SHUATS Allahabad. The self-propelled reaper binder (Make: BCS; model: 3LD-450 S) under study was a hand guided, walking type, light weight air cooled diesel engine (10.5 hp) operated compact machine. The self-propelled reaper binder mainly consists of a cutter bar, power unit, power transmission unit, bundling unit and the frame.

\section{Feature of self propelled reaper binder}

The cutter bar of selected reaper binder was $1.2 \mathrm{~m}$ wide. Four forward and one reverse gear was provided on the machine. It was steered by hand operated brakes and foot operated pedal for turning left or right. The crop row dividers helped the standing crop to enter the machine, by the 'raising ups' gently push the crop towards cutter bar and push the crop on to the crop conveying chain. The star wheel kept the cut crop in upright position towards crop conveyors. The crop was gathered at the knottier mechanism when sufficient quantity of crop is gathered; the bundle was tied and ejected by the ejecting fingers out of machine. An auxiliary conveyer carried the bundle away from the machine on the ground. The bundle size was adjustable with in limit.

\section{Measurement of all parameters}

\section{Actual working time}

The actual working time was measured in the field using a stop watch. The time losses due to turnings were not taken into account. Time lost in breakdowns were recorded and deducted from the total time.

\section{Speed of operation}

The speed of operation was taken as independent variable to see its effect on various performance parameters like height of cut, grain losses and field capacity etc. of the reaper binder. The speed of operation was varied from 1.9 to $2.55 \mathrm{~km} \mathrm{~h}^{-1}$.

\section{Effective field capacity}

Effective field capacity was measured by the actual area covered by the reaper-binder, based on its total time consumed and its width. Effective field capacity was determined by the following relationship 
Effective field capacity $\left(\right.$ ha $\left.\mathrm{h}^{-1}\right)=$ Area covered (ha)/time taken (h).

\section{Theoretical field capacity}

Theoretical field capacity is the rate of field coverage of the machine, based on 100 per cent of time at the rated speed and covering 100 per cent of its rated width. The theoretical field capacity was determined by using the following relationship:

Theoretical field capacity $\left(\mathrm{ha} \mathrm{h}^{-1}\right)=$ Actual width of cut $(\mathrm{m}) \mathrm{x}$ speed $\left(\mathrm{km} \mathrm{h}^{-1}\right) / 10$

\section{Field efficiency}

It is ratio of effective field capacity and the theoretical field capacity. It takes into account the time losses encountered in the field due to various reasons. Field efficiency was calculated as below.

Field Efficiency $(\%)=$ Effective field capacity $\left(\right.$ ha $\left.\mathrm{h}^{-1}\right) /$ Theoretical field capacity $\left(\right.$ ha $\left.\mathrm{h}^{-1}\right) \mathrm{x}$ 100

\section{Fuel consumption}

The fuel consumption of reaper binder at different operating speeds varied from $1 \mathrm{l} \mathrm{h}^{-1}$ to $1.21 \mathrm{l} \mathrm{h}^{-1}$. The minimum fuel consumption of $11 \mathrm{~h}^{-1}$ was recorded at minimum operating speed of $1.9 \mathrm{~km} \mathrm{~h}^{-1}$. However the maximum fuel consumption of $1.21 \mathrm{~h} \mathrm{~h}^{-1}$ was recorded at forward speed $2.25 \mathrm{~km} \mathrm{~h}^{-1}$.

\section{Labour requirement}

The number of labors required for harvesting, collection and time taken for these operations were recorded.

\section{Crop parameters}

The condition of crop, crop density, plant height and moisture content of grain as well as straw were measured of Wheat crop (var.
DBW-17). Following crop parameters were measured.

\section{Moisture content of crop}

During the testing the samples of grain were weighed and the sample box with sample was placed in an oven for 48 hours at $80^{\circ} \mathrm{C}$. The straw samples were chopped in small pieces approx. $92.3 \mathrm{~cm}$ and samples were weighed and dried as described for grain. The moisture content was calculated as follows:

Moisture content, $(\%)=\mathrm{W}_{1}-\mathrm{W}_{2} / \mathrm{W}_{2} \times 100$ $\mathrm{W}_{1^{-}}$The initial weight of the grains, $\mathrm{W}_{2^{-}}$The final weight of the grains after drying.

\section{Height of plant}

The wheat crop was harvested by manual operation as close as possible to the ground and samples were collected randomly in farmers' field. The average height of crop was $78.5 \mathrm{~cm}$ which are measured by measuring tape.

\section{Density of crop}

The density of crops measured in farmers' field with $1 \mathrm{~m}^{2}$ square cast iron frame at five random places in the plot. In which area, crop was cut manually by sickle. The number of plants cut from these places gave the crop density in plants $/ \mathrm{m}^{2}$.

\section{Height of cut}

The height of cut both for reaper binder harvesting and manual method is presented in table 3 as evident from this table, the height of cut with the reaper binder varied from 5 to 7 . $\mathrm{cm}$. Whereas for manual harvesting the variation was 0.8 to $1.1 \mathrm{~cm}$.

\section{Width of cut}

It can be observed that actual width of cut varied from 90 to $120 \mathrm{~cm}$ against the rated 
width of $120 \mathrm{~cm}$. From this data, it is clear that the width of cut was almost constant with the variation in the speed of operation.

\section{Uncut plants}

The number of uncut plants (on $\%$ basis) is determined as the ratio of no. of uncut plants after harvesting to the no. of plants before harvesting multiplied by 100 (for 1 ha area).

\section{Working width of implement}

Working width of implement gives the width of cut of the crop in the field. It is an important variable in finding out the effective field capacity of the implement. To measure the working width of the implement firstly the center of the experimental field was marked. Then the distance of the outermost uncut crop on either side of the center of the plot was measured. Now the implement was made to cut another row of crop and the distance of the outermost uncut plant from the same point at the center of the plot was measured using a metallic tape. It was measured respective row was cut on either side of the plot from the center of the field.

\section{Harvesting losses}

\section{Pre harvesting losses}

To measure the pre harvest loss an area of $1 \mathrm{~m}^{2}$ was harvested manually using a sickle. Care was taken that there were no shattering losses. The grains and ear heads, which had fallen within $1 \mathrm{~m}^{2}$ Iron frame were collected and weighed. This pre harvest loss $\left(\mathrm{W}_{0}\right)$ in $\mathrm{g} / \mathrm{m}^{2}$ was repeated at seven different places chosen randomly in every plot.

\section{Shattering loss}

It is defined as the amount of the grains and ear heads fallen on the ground due to the shattering action of the reaper binder cutter bar and conveying. After operation of reaper binder same procedure of pre harvesting losses was repeated to get shattering loss $\left(\mathrm{W}_{1}\right)$ in $\mathrm{g} / \mathrm{m}^{2}$.

\section{Collection loss}

Collection loss is defined as the amount of grain an ear heads fallen during windrowing, collection and bundling of the crop. To measure this loss a $12 \mathrm{~m}$ long and $1 \mathrm{~m}$ wide polythene sheet was lain adjacent to the standing crop. The harvest crop fell on the polythene sheet was picked and bounded manually. The grain and ear heads remaining on the polythene sheet were collected and weight. This gave collection loss $\left(\mathrm{W}_{2}\right)$ in $\mathrm{g} / \mathrm{m}^{2}$.

These samples were taken from whole plot. In the similar way, the total harvesting losses were calculated described as follows.

Harvesting losses $=$ Shattering loss $\left(\mathrm{W}_{0}\right)+$ Collection loss $\left(\mathrm{W}_{1}\right)+$ Pre harvest loss $\left(\mathrm{W}_{2}\right)$

\section{Cost analysis}

Cost analysis was carried out to compare the economics of the reaper binder over manual harvesting. As suggested by Kepner, (1952) the cost of operation was calculated.

\section{Instrumentation}

There are some instruments for used during the experiment (Table 1).

\section{Results and Discussion}

The performance evaluation of the selfpropelled reaper binder was obtained during the field tests by harvesting of wheat crop.

\section{Crop conditions}

The variety of crop, average height of plants and moisture content in grain and straw obtained from each plot is shown in table 2 . 


\section{Performance of reaper binder}

The performance of the reaper binder was based on average height of cut $56 \mathrm{~mm}$, forward speed $2.28 \mathrm{~km} \mathrm{~h}^{-1}$, actual width of cut $940 \mathrm{~mm}$, actual field capacity $0.166 \mathrm{ha} \mathrm{h}^{-1}$, field efficiency $73.46 \%$, fuel consumption $1.12 \mathrm{l} \mathrm{h}^{-1}$, labor and the loss occurring in the field while harvesting is shown in table 3 (Fig. 1 and 4).

\section{Grain losses for harvesting}

The amount of grain loss due to shattering, windrowing, collection and bundling for reaper binder and manual harvesting with sickle are shown in table 4, figure 5 and the average pre harvest losses both for reaper and manual harvested plants were 2.3 to $2.2 \mathrm{~kg} \mathrm{~h}^{-1}$ respectively. However, it was noticed that with decrease in grain moisture content from 11.53 to $9.56 \%$, the pre harvest losses were increased from $1.5 \mathrm{~kg} \mathrm{ha}^{-1}$, Shows that the crop dries the per-harvest losses will increase. The average collection losses for manual and reaper binder harvesting varied from 4.7 to 5.2 $\mathrm{kg} \mathrm{ha}^{-1}$ and 4.1 to $5.1 \mathrm{~kg} \mathrm{ha}^{-1}$ respectively. The total grain losses in manual harvesting were extremely high $119.5 \mathrm{~kg} \mathrm{ha}^{-1}$ as compared to reaper harvesting $18.5 \mathrm{~kg} \mathrm{ha}^{-1}$. The shattering losses were very high with sickle as compared to reaper harvesting. For manual harvesting, shattering losses varied from 95.5 to $114 \mathrm{~kg}$ $\mathrm{ha}^{-1}$ whereas with reaper binder shattering losses were in the range of 7.9 to $14.3 \mathrm{~kg} \mathrm{ha}^{-1}$.

\section{Cost analysis}

The total cost of operation of the self propelled reaper binder was found to be Rs.3235.11 per hectare. It has been assumed that the reaper would be used for about 300 hours. The cost of harvesting with manual method is Rs. 5500 per hectare (Fig. 6).

\section{Farmer's reaction}

The reaction of the local village people about the operations of self propelled vertical conveying reaper binder was as follows:

The local people felt that the reaper binder reduces the labour requirement of harvesting. They appreciated the tremendous reduction in the grain losses by using the reaper binder.

They appreciated the fact that the use of reaper binder would make the harvesting of crops timely.

The people complained of the problems maneuverability of the machine.

Table.1 Instruments used during the experiment

\begin{tabular}{|c|l|l|c|c|}
\hline S. No. & Name of instrument & Purpose & L.C. & Max. \\
\hline 1. & Measuring cylinder & Fuel consumption & $1 \mathrm{ml}$ & 51 \\
\hline 2. & Stop watch & Time & $0.1 \mathrm{~s}$ & $30 \mathrm{~min}$ \\
\hline 3. & Physical balance & Weighing of sample & $0.01 \mathrm{~g}$ & $100 \mathrm{~g}$ \\
\hline 4. & Pan balance & Weighing of sample & $0.5 \mathrm{~g}$ & $1 \mathrm{~kg}$ \\
\hline 5. & Measuring tape & Linear distance & $1 \mathrm{~cm}$ & $50 \mathrm{~m}$ \\
\hline 6. & Measuring scale & Linear distance & $1 \mathrm{~mm}$ & $30 \mathrm{~cm}$ \\
\hline
\end{tabular}


Table.2 Condition of the crop before the test

\begin{tabular}{|c|c|c|c|c|c|}
\hline Plot Name & $\begin{array}{c}\text { Area of Plot } \\
(\mathbf{m} \times \mathbf{m})\end{array}$ & $\begin{array}{c}\text { Variety of } \\
\text { crop }\end{array}$ & $\begin{array}{c}\text { Average } \\
\text { height of } \\
\end{array}$ & & \multicolumn{2}{|c|}{ Moisture content (\%) } \\
\cline { 5 - 6 } & & plants $(\mathbf{c m})$ & Grain & Straw \\
\hline $\mathbf{A}$ & $30 \times 35$ & $\mathrm{DBW}-17$ & 77 & 11.53 & 12.15 \\
\hline $\mathbf{B}$ & $40 \times 40$ & $\mathrm{DBW}-17$ & 79 & 10.20 & 9.67 \\
\hline $\mathbf{C}$ & $50 \times 50$ & $\mathrm{DBW}-17$ & 80 & 9.82 & 8.96 \\
\hline $\mathbf{D}$ & $30 \times 33$ & $\mathrm{DBW}-17$ & 78 & 9.56 & 8.32 \\
\hline Average & & & 78.5 & 10.27 & 9.77 \\
\hline
\end{tabular}

Table.3 Field performance data of the self propelled reaper binder

\begin{tabular}{|c|c|c|c|c|c|c|c|c|c|}
\hline \multirow[t]{2}{*}{$\begin{array}{l}\text { Plot } \\
\text { Name }\end{array}$} & \multirow{2}{*}{$\begin{array}{c}\text { Average } \\
\text { height of } \\
\text { cut } \\
\text { (mm) }\end{array}$} & \multirow{2}{*}{$\begin{array}{c}\text { Forward } \\
\text { speed } \\
\left(\mathbf{k m ~ h}^{-1}\right)\end{array}$} & \multirow{2}{*}{$\begin{array}{c}\text { Actual } \\
\text { width of } \\
\text { cut } \\
(\mathbf{m m})\end{array}$} & \multirow{2}{*}{$\begin{array}{c}\text { Actual } \\
\text { field } \\
\text { capacity } \\
\left(\mathbf{h a ~ h}^{-1}\right)\end{array}$} & \multirow{2}{*}{$\begin{array}{l}\text { Total } \\
\text { time for } \\
\text { harvest } \\
\left(\mathrm{g} \mathrm{min}^{-1}\right)\end{array}$} & \multirow{2}{*}{$\begin{array}{c}\text { Field } \\
\text { efficienc } \\
\mathbf{y}(\%)\end{array}$} & \multirow{2}{*}{$\begin{array}{c}\text { Fuel } \\
\text { consumpti } \\
\text { on }\left(\mathbf{l ~ h}^{-1}\right)\end{array}$} & \multicolumn{2}{|c|}{$\begin{array}{l}\text { Labour requirement } \\
\qquad\left(\mathrm{man}-\mathrm{h} \mathbf{h a}^{-1}\right)\end{array}$} \\
\hline & & & & & & & & Skilled & Unskilled \\
\hline A & 55 & 1.9 & 920 & 0.149 & 42 & 78.49 & 1.0 & 6.7 & 51.08 \\
\hline B & 58 & 2.2 & 930 & 0.158 & 61 & 72.07 & 1.07 & 6.3 & 49.62 \\
\hline C & 57 & 2.45 & 940 & 0.169 & 94 & 69.17 & 1.2 & 5.9 & 43.94 \\
\hline D & 56 & 2.55 & 960 & 0.189 & 32 & 74.11 & 1.21 & 5.29 & 46.29 \\
\hline Average & 56 & 2.28 & 940 & 0.166 & 57.25 & 73.46 & 1.12 & 6.04 & 47.73 \\
\hline
\end{tabular}

Fig.1 Traveling condition of self propelled reaper binder

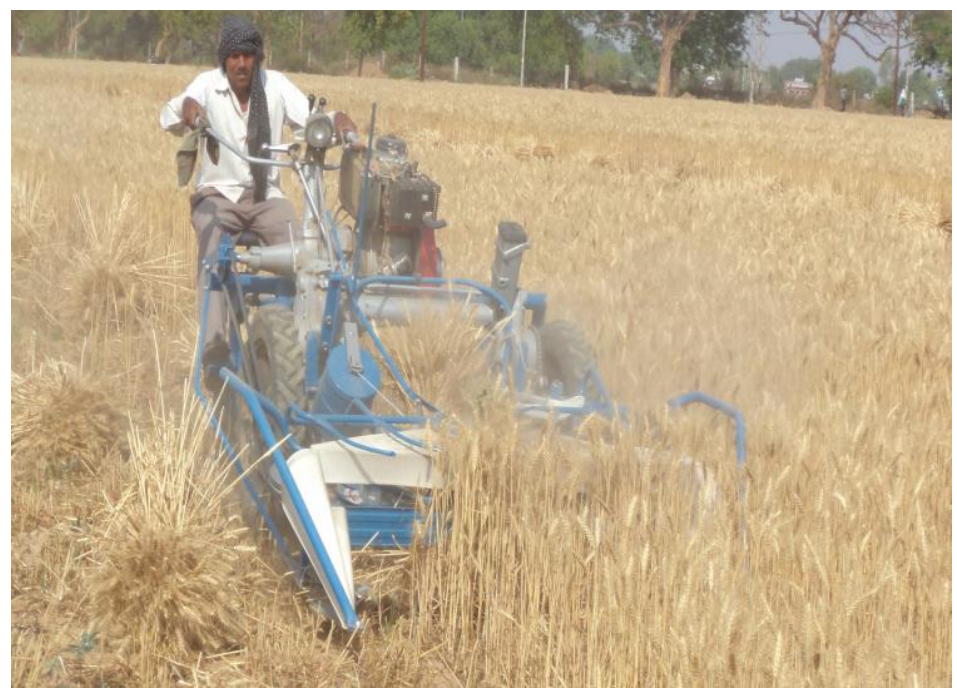


Fig.2 Effect of speed on the actual field capacity of the reaper binder

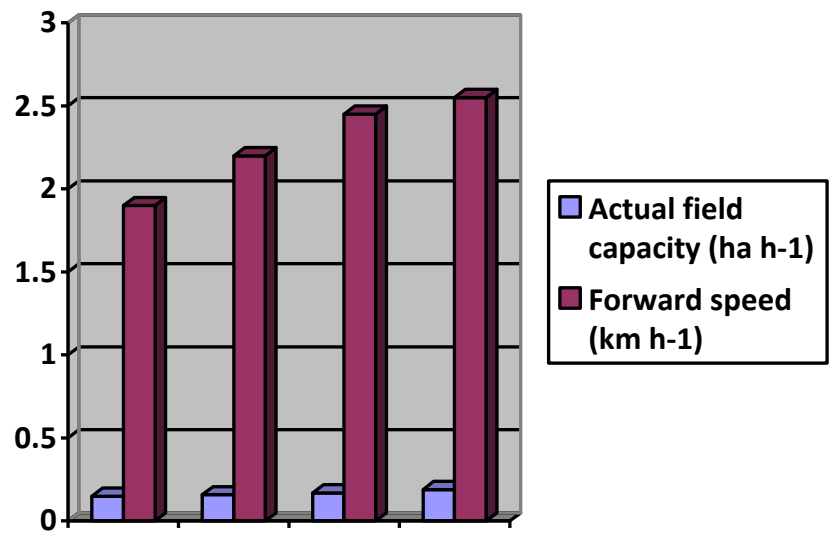

Fig.3 Effect of speed on the field efficiency of the reaper binder

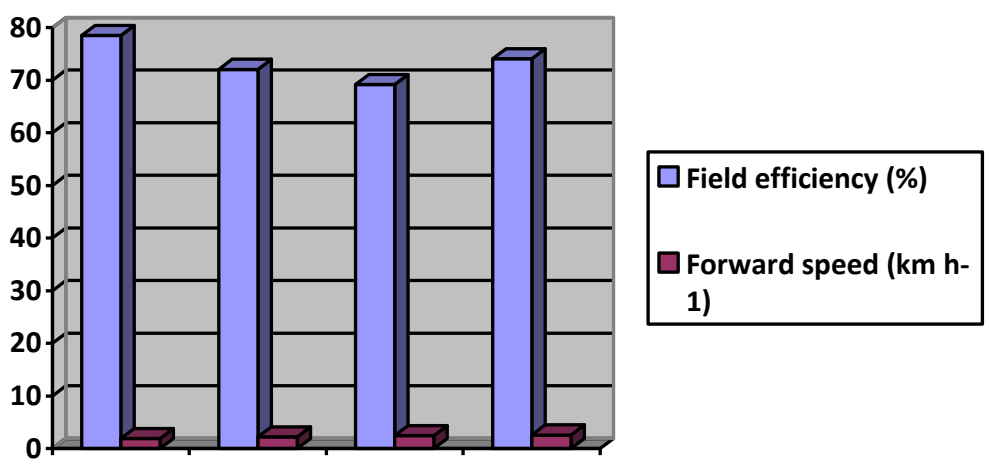

Fig.4 Effect of speed on the fuel consumption of the reaper binder

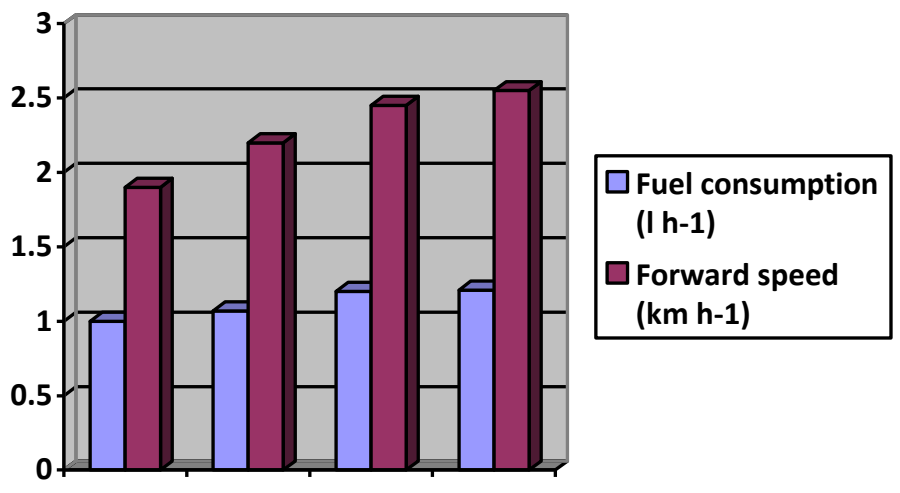


Fig.5 Effect of speed on the total grain losses

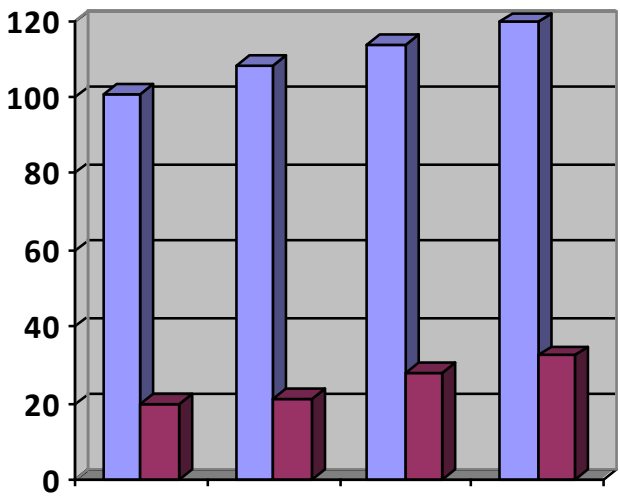

$\square$ Manual

$\square$ Mechanical

Fig.6 Comparison of manual and reaper binder cost of operation

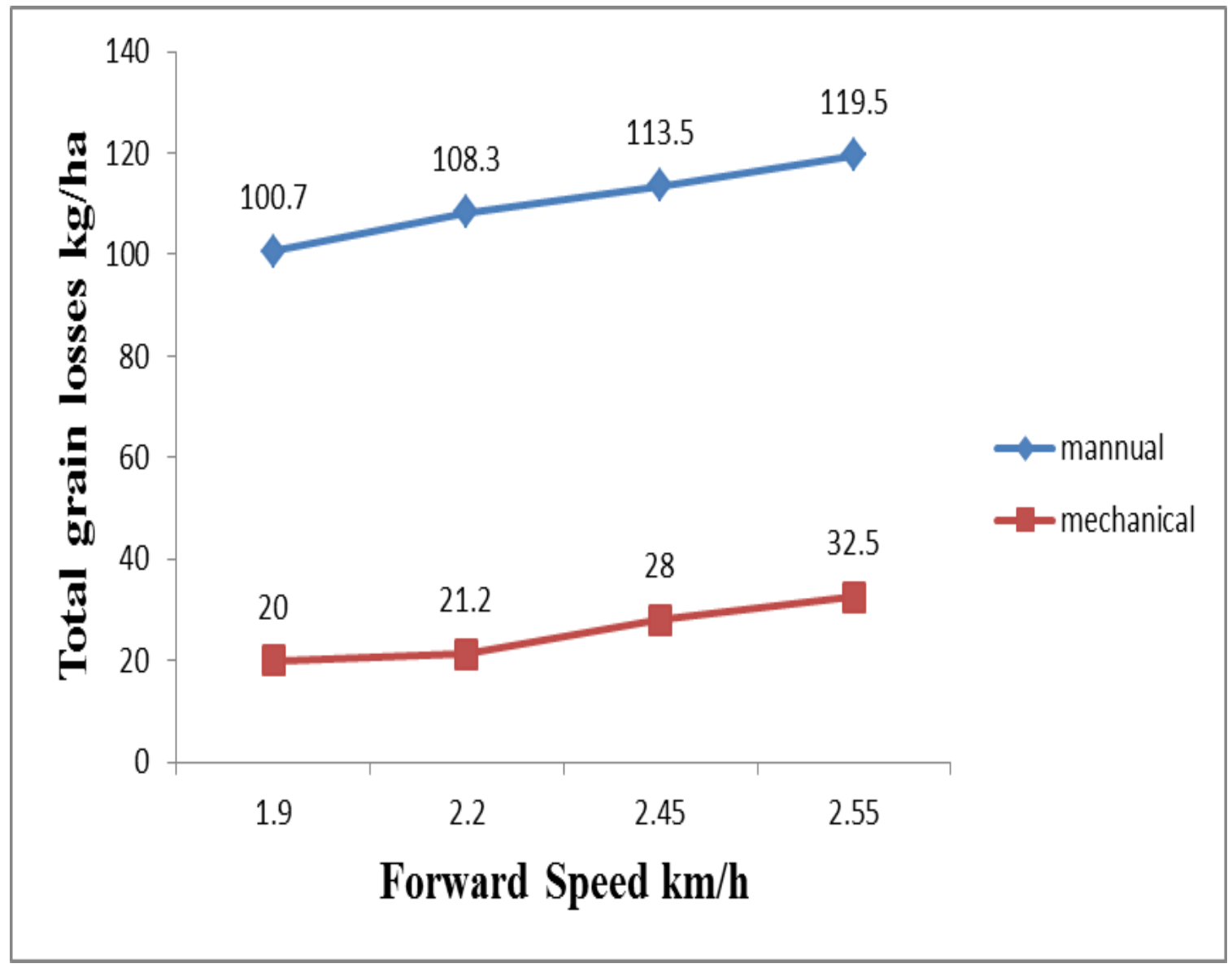


Int.J.Curr.Microbiol.App.Sci (2018) 7(12): 896-906

Table.4 Grain losses with manual and reaper operation

\begin{tabular}{|c|c|c|c|c|c|c|c|c|c|c|}
\hline \multirow[t]{2}{*}{$\begin{array}{l}\text { Plot } \\
\text { Name }\end{array}$} & \multirow{2}{*}{$\begin{array}{c}\text { Speed } \\
\mathbf{k m ~ h}^{-}\end{array}$} & \multirow{2}{*}{$\begin{array}{c}\text { Moisture } \\
\text { content } \\
(\%)\end{array}$} & \multicolumn{2}{|c|}{$\begin{array}{l}\text { Pre-harvest loss } \\
\quad\left(\mathrm{kg} \mathrm{ha}^{-1}\right)\end{array}$} & \multicolumn{2}{|c|}{$\begin{array}{l}\text { Shattering loss } \\
\qquad\left(\mathrm{kg} \mathrm{ha}^{-1}\right)\end{array}$} & \multicolumn{2}{|c|}{$\begin{array}{l}\text { Collection loss } \\
\quad\left(\mathrm{kg} \mathrm{ha}^{-1}\right)\end{array}$} & \multicolumn{2}{|c|}{$\begin{array}{l}\text { Total grain losses } \\
\quad\left(\mathrm{kg} \mathrm{ha}^{-1}\right)\end{array}$} \\
\hline & & & Manual & Mechanical & Manual & Mechanical & Manual & Mechanical & Manual & Mechanical \\
\hline $\mathbf{A}$ & 1.9 & 11.53 & 1.5 & 1.2 & 95.5 & 17.9 & 5.2 & 0.9 & 100.7 & 20.0 \\
\hline B & 2.2 & 10.20 & 1.5 & 1.9 & 103.0 & 18.6 & 5.3 & 0.7 & 108.3 & 21.2 \\
\hline C & 2.45 & 9.82 & 2.1 & 2.9 & 108.7 & 24.1 & 4.8 & 1.0 & 113.5 & 28 \\
\hline D & 2.55 & 9.56 & 3.7 & 3.2 & 114.8 & 28.3 & 4.7 & 1.0 & 119.5 & 32.5 \\
\hline Average & - & 10.28 & 2.2 & 2.3 & 105.5 & 22.22 & 5.0 & 0.9 & 110.5 & 25.425 \\
\hline
\end{tabular}


In conclusions, a self propelled reaper binder was tested for its performance in the research form, SHUATS, Allahabad. The performance of the reaper binder with respect to field capacity, field efficiency, fuel consumption, harvesting losses, labour requirement and cost of operation were studied and compared with manual harvesting method, the following conclusions are drawn.

The operating speed of reaper binder could be varied from 1.9 to $2.55 \mathrm{~km} \mathrm{~h}^{-1}$.

The average operating width of the reaper binder was found to be $94 \mathrm{~cm}$ of the rated width.

The height of cut varied from 5 to $7 \mathrm{~cm}$, which was acceptable to the farmers.

The total grain losses in reaper binder harvesting were only $25.425 \mathrm{~kg} \mathrm{ha}$ as compared to $119.5 \mathrm{~kg} \mathrm{ha}^{-1}$ with manual harvesting.

The reaper binder harvesting grain losses were less than $1 \%$ while for manual harvesting, it was around $4 \%$.

The fuel consumption of reaper binder harvesting varied from 1.0 to 1.2 liters $\mathrm{h}^{-1}$ with different operating speeds.

The field capacity of the reaper binder at 2.55 $\mathrm{km} \mathrm{h}^{-1}$ was $0.19 \mathrm{ha} \mathrm{h}^{-1}$. This means that time required for harvesting one hectare of wheat crop was $5.26 \mathrm{~h}$.

The field efficiency of the reaper binder varied from 69.17 to $78.49 \%$.

The cost of harvesting with reaper binder and manual harvesting was only Rs. 3235.11 and Rs.5550 per hectare.

\section{References}

Devnani, R.S; Pandey, M.M. (1979) Evaluation of field performance of reaper binder for harvesting of wheat crop, Journals of Agril.
Engg. Vol. 17: No.1.

Devnani, R.S; Pandey, M.M. (1985) Design development and field evaluation of vertical conveyor reaper windrower. AMA. 16(2): 4151.

Devnani, R.S; Pandey, M.M. (1984) Development and field evaluation of vertical conveyor reaper wind-rower, Journal of Agril. Engg. ISAE, Vol. 21 No. 4.

Gajendra Singh, Amjad; P. Chaudhary and David Gee. Clough (1988) Performance Evaluation of mechanical Reaper in Pakistan, Journals of Agril. Mechanization in Asia, Africa \& Latin America, Vol. 19, No. 3.

Iqbal S, Premalatha S, Asfa Zahra (1985) International journal of Dermatology, Wiley Online Library.

Kepner, R.A. (1952) Analysis of cutting section of mower, Agril. Engg. 7(1): 10-18.

Manes, G.S.; Sandhar, N.S.; Bal, A.S. and H.M. Khurana. (2003) Comparative performance of combine harvester. Journals of Agril. Engg. Vol. 27 (1-2): No. 7-14.

Mishra, R.S. (1983) Field trail on reaper binder, Journals of Agril. Engg. Vol. 17, No. 2.

Pathak, S. V., Pawar, C.S. and Shirsat, N.A. (2008) Performance evaluation of combine harvester and combination of self-propelled vertical conveyor reaper with thresher for wheat harvesting, Ag. update, Feb-July (2008), Vol. 3 (1\&3): 123-126.

Sexena, B.B. and T.P. Ojha (1985) Determining the effect of harvesting date on yield potential of soyabean. Proceedings of silver jubilee convention. ISAE.83.

Tuteja, P.K., S.C.L. Premi and R.C. Hasija (1996) Constraints in adoption of vertical conveyer reaper in selected districts of Haryana. Agril. Engg. Today, 20(9): 78-83.

Yadav, R.N.S. and B.G. Yadav (1992) Design and development of CIAE Bullock- drawn reaper. AMA, 23 (2): 34-43.

\section{How to cite this article:}

Anurag Patel, Rajkishor Singh, Prabhakar Shukla and Moses, S.C. 2018. Performance Evaluation of Self Propelled Reaper Binder for Harvesting of Wheat Crop. Int.J.Curr.Microbiol.App.Sci. 7(12): 896906. doi: https://doi.org/10.20546/ijcmas.2018.712.112 